\title{
EFEKTIVITAS PEMBELAJARAN MATEMATIKA MELALUI PENERAPAN METODE INDEX CARD MATCH PADA SISWA KELAS VII SMP NASIONAL MAKASSAR
}

\author{
Mudrika Aulia Hamka ${ }^{1}$ \\ Sitti Rahmah Tahir ${ }^{2 *}$ \\ Djadir $^{3}$ \\ ${ }^{1,2}$ Prodi Pendidikan Matematika, Universitas Muhammadiyah Makassar, Indonesia \\ ${ }^{3}$ Universitas Negeri Makassar, Makassar, Indonesia
}

\begin{abstract}
Abstrak
Jenis penelitian ini adalah penelitian pra-eksperimen yang melibatkan satu kelas sebagai kelas eksperimen yang bertujuan untuk mengetahui efektivitas metode Index Card Match pada pembelajaran matematika siswa kelas VII SMP Nasional Makassar. Desain penelitian yang digunakan adalah The One Group Pretest Posttest. Sampel eksperimennya adalah siswa kelas VII.F SMP Nasional Makassar. Alat pengumpulan data adalah tes hasil belajar, lembar observasi aktivitas siswa dan angket respons siswa, serta lembar keterlaksanaan pembelajaran. Hasil penelitian secara inferensial menunjukkan bahwa: (1) Hasil belajar matematika siswa lebih dari atau sama dengan nilai KKM 75 (2), Ketuntasan klasikal lebih dari atau sama dengan 75\% (3) Gain atau peningkatan hasil belajar minimal dalam kategori sedang. Hasil deskriptif menunjukkan bahwa (1) rata-rata nilai keterlaksanaan pembelajaran mencapai 3,32 termasuk kategori terlaksana dengan sangat baik (2) skor rata-rata posttest 83,25 lebih besar dari pada skor rata-rata pretest 58,46 dengan standar deviasi pretest 12,99 dan posttest 8,49 . Dari hasil tersebut juga diperoleh bahwa pada pretest tidak satupun atau $0 \%$ siswa yang mencapai kriteria ketuntasan minimal. Pada posttest ada 22 siswa atau 91,67\% telah mencapai ketuntasan individual dan terdapat 2 atau 8,33\% siswa tidak mencapai ketuntasan individual. Dalam hal ini berarti ketuntasan klasikal telah tercapai. Selain itu, terjadi peningkatan hasil belajar dimana nilai rata-rata gain ternormalisasi yaitu 0,64. (3) Rata-rata persentase frekuensi aktivitas siswa yaitu 82,92\% maka aktivitas siswa mencapai kriteria aktif dan (4) respons siswa menunjukkan positif dimana rata-rata persentasenya adalah 90,53\%. Dengan demikian metode Index Card Match efektif diterapkan dalam pembelajaran matematika pada siswa kelas VII SMP Nasional Makassar.
\end{abstract}

Kata Kunci: Index Card Match, Hasil Belajar Siswa, Aktivitas Siswa, Respon Siswa

\section{Pendahuluan}

Pendidikan menjadi salah satu cara tepat untuk meningkatkan pembangunan manusia di suatu negara. Hal ini tercantum dalam rumusan Pendidikan nasional menurut Undang-Undang Nomor 20 Tahun 2003 berbunyi: Pendidikan adalah usaha sadar dan terencana untuk mewujudkan suasana belajar dan proses pembelajaran agar peserta didik secara aktif mengembangkan potensi dirinya untuk memiliki kekuatan spiritual, keagamaan, pengendalian diri, kepribadian, kecerdasan, akhlak mulia, serta keterampilan yang dibutuhkan bagi dirinya, 
masyarakat, dan bangsa. Tujuan pendidikan akan tercapai jika pembelajaran bisa berjalan efektif. Pendidikan memegang peranan yang sangat penting dalam usaha mengembangkan kualitas manusia dan pendidikan. Kualitas manusia dapat dilihat dari kualitas pendidikan sumber daya manusia itu sendiri, dan dua indikator untuk melihat kualitas pendidikan yaitu dilihat dari hasil belajar siswa yang baik dan berbagai bidang diantaranya matematika.

Namun kenyataan di lapangan masih banyak siswa yang menganggap bahwa matematika itu sebagai mata pelajaran yang kurang menarik, kurang disenangi dan dirasa sulit. Rendahnya hasil belajar matematika siswa juga terjadi, hal tersebut terlihat dari kemampuan matematika pada siswa SMP Nasional Makassar yang hanya mencapai skor rata-rata nilai 63,15 pada semester genap 2018/2019 sedangkan nilai KKM (Krteria Ketuntasan Minimal) yang ditetapkan di sekolah tersebut, yaitu 75,00 dari skor ideal 100.

Solusi mengatasi masalah di atas, perlu dikembangkan strategi pembelajaran yang dapat meningkatkan semangat dan aktivitas siswa. Salah satunya ialah penerapan stratefi belajar aktif tipe Index Card Match. Strategi belajar aktif tipe Index Card Match merupakan salah satu pembelajaran yang menyenangkan dan aktif untuk meninjau ualang materi pembelajaran sebelumnya dan sesudahnya yang pernah diajarkan yang ditandai dengan cara bermain kartu dengan cara mencari pasangan menggunakan potongan kertas yang berisikan pertanyaan serta jawaban. Metode Index Card Match ini berhubungan dengan cara-cara untuk mengingat kembali apa yang telah mereka pelajari dan menguji pengetahuan serta kemampuan mereka saat ini dengan teknik mencari pasangan kartu yang merupakan jawaban atau soal sambil belajar mengenai suatu konsep atau topik dalam suasana menyenangkan. Dalam stretegi pembelajaran ini siswa dituntut untuk menguasai dan memahami konsep melalui pencarian kartu indeks, dimana kartu indeks terdiri dari dua bagian yaitu kartu soal dan kartu jawaban. Setiap siswa memiliki kesempatan untuk memperoleh satu buah kartu. Dalam hal ini siswa diminta mencari pasangan dari kartu yang diperilehnya, siswa yang mendapat kartu soal mencari siswa yang memiliki kartu jawaban, demikian sebaliknya. Strategi pembelajaran ini mengandung unsur penilaian sehingga diharapkan siswa tidak bosan dalam belajar.

Salah satu bentuk strategi pembelajaran aktif adalah metode pembelajaran Index Card Match. Muttaqien (2006), Metode Index Card Match memiliki tiga bagian inti, yaitu (1) bagaimana menjadikan siswa aktif sejak awal, (2) bagaimana membantu siswa mendapatkan pengetahuan, keterampilan, dan sikap secara aktif, dan (3) bagaimana menjadikan belajar tak terlupakan. Metode Index Card Match ini berhubungan dengan cara-cara untuk mengingat kembali apa yang telah mereka pelajari dan menguji pengetahuan serta kemampuan mereka saat ini dengan teknik mencari pasangan kartu yang merupakan jawaban atau soal sambil 
belajar mengenai suatu konsep atau topik dalam suasana menyenangkan. Hisyam Zaini dkk, (2008: 67) memaparkan bahwa Index Card Macth merupakan salah satu strategi yang cukup menyenangkan untuk mengulang materi yang telah diberikan sebelumnya.

Beberapa guru dalam kegiatan belajar mengajar memberikan banyak informasi kepada siswa agar materi ataupun topik dalam program pembelajaran dapat terselesaikan tepat waktu, namun guru terkadang lupa bahwa tujuan pembelajaran bukan hanya materi yang selesai tepat waktu tetapi sejauh mana materi telah disampaikan dapat diingat oleh siswa. Karena itu dalam kegiatan pembelajaran perlu diadakan peninjauan ulang atau review untuk mengetahui apakah materi yang disampaikan dapat dipahami oleh siswa.

Menurut Hamruni (2012) Index Card Match adalah cara menyenangkan lagi aktif untuk meninjau ulang materi pembelajaran. Berdasarkan pendapat para ahli tersebut, metode Index Card Match merupakan salah satu metode yang menuntut siswa untuk bekerjasama dan dapat meningkatkan rasa tanggung jawab atas apa yang dipelajari dengan cara yang menyenangkan. Muttaqien (2006) mengemukakan langkah-langkah pembelajaran dengan metode Index Card Match ini adalah:

a. Pada kartu indeks yang terpisah, guru menulis pertanyaan tentang apapun yang diajarkan di kelas. Guru membuat kartu pertanyaan dengan jumlah yang sama dengan setengah jumlah siswa.

b. Pada kartu yang terpisah, guru menulis jawaban atau masingmasing pertanyaan itu.

c. Dua kumpulan kartu itu dicampur dan dikocok beberapa kali agar benar-benar tercampur aduk.

d. Guru memberikan satu kartu untuk setiap siswa. Guru menjelaskan bahwa ini merupakan latihan pencocokan. Sebagian siswa mendapatkan pertanyaan tinjauan dan sebagian lagi mendapatkan kartu jawabannya.

e. Guru memerintahkan siswa untuk mencari kartu pasangan mereka. Bila sudah terbentuk pasangan, siswa yang berpasangan diperintahkan untuk mencari tempat duduk bersama (katakan pada mereka untuk tidak mengungkapkan kepada pasangan lain apa yang ada di kartu mereka).

f. Bila pasangan yang cocok telah duduk bersama, guru memanggil siswa secara acak untuk membacakan soal tiap pasangan untuk memberikan kuis kepada siswa lain dengan membacakan pertanyaan mereka dan menantang siswa lain untuk memberikan jawabannya. 
Langkah-langkah yang sama juga disampaikan oleh Hamruni (2012), Sedangkan menurut Zaini et al. (2008) langkah - langkah strategi pembelajaran Index Card Match adalah sebagai berikut:

a. Buatlah potongan-potongan kertas sejumlah peserta didik yang ada dalam kelas. Bagi jumlah kertas-kertas tersebut menjadi dua bagian yang sama.

b. Tulis pertanyaan tentang materi yang telah diberikan sebelumnya pada setengah bagian kertas yang telah disiapkan, setiap kertas berisi satu pertanyaan. Pada separuh kertas yang lain, tulis jawaban dari pertanyaan-pertanyaan yang tadi dibuat.

c. Kocoklah semua kertas sehingga akan tercampur antara soal dan jawaban.

d. Bagi setiap peserta didik satu kertas. Jelaskan bahwa ini adalah aktivitas yang dilakukan berpasangan. Saparuh peserta didik akan mendapatkan soal dan separuh yang lain akan mendapatkan jawaban.

e. Yang sudah menemukan pasangan, minta mereka untuk duduk berdekatan. Terangkan juga mereka tidak memberitahu materi yang mereka dapatkan kepada teman yang lain.

f. Setelah semua peserta didik menemukan pasangan, dan duduk berdekatan, minta setiap pasangan secara bergantian untuk membacakan soal yang diperoleh dengan keras kepada temanteman yang lain. Selanjutnya soal tersebut dijawab oleh pasangan yang lain.

g. Akhiri proses dengan membuat klarifikasi dan kesimpulan. Implementasi metode pembelajaran Index Card Match dapat dilakukan dengan beberapa modifikasi atau variasi. Pada penelitian ini, langkah-langkah yang diterapkan adalah langkah-langkah menurut Muttaqien (2006) yang telah diuraikan.

Berdasarkan uraian diatas permasalahan yang akan dikaji dalam penelitian ini adalah apakah metode pembelajaran Index Card Match efektif diterapkan dalam pembelajaran matematika pada siswa kelas VII SMP Nasional Makassar? Tujuan dari penelitian ini adalah untuk mengetahui efektivitas metode pembelajaran Index Card Match efektif diterapkan dalam pembelajaran matematika pada siswa kelas VII SMP Nasional Makassar.

\section{Metode Penelitian}

Jenis penelitian yang digunakan dalam penelitian ini adalah pra eksperimen dengan desaian one grup pretest-posttest Design. Dalam desain ini terdapat satu kelompok yang masing-masing dipilih secara random (R). sebelum diberi perlakuan kelompok diberi tes awal atau pretest untuk mengukur kondisi awal $\left(O_{1}\right)$. Selanjutnya pada kelompok tersebut diberi perlakuan berupa pengajaran melalui metode Index Card Match (T) dan setelah perlakuan 
kelompok diberi tes kembali sebagi tes akhir (Posttest) $\left(\mathrm{O}_{2}\right)$.

Adapun anggota populasi dalam penelitian ini adalah seluruh siswa kelas VII SMP Nasional Makassar Tahun ajaran 2019/2020 yang tersebar dalam 6 kelas yaitu kelas VII.A, kelas VII.B, kelas VII.C, kelas VII.D, kelas VII.E, dan kelas VII.F, dengan jumlah siswa sebanyak 150 orang. Tiap kelas memiliki jumlah rata-rata 24 orang. Pengambilan sampel dalam penelitian ini dilakukan dengan menggunakan teknik simple random sampling. Dalam penelitian ini kelas sampel diperoleh dengan mengambil satu kelas secara acak dari populasi. Sampel yang terpilih adalah siswa kelas VII SMP Nasional Makassar dengan jumlah siswa 24 orang. Teknik pengumpulan data dalam penelitian ini adalah tes hasil belajar, observasi aktivitas siswa, dan angket respons siswa. Teknik analisis data yang digunakan dalam penelitian ini adalah analisis statistik deskriptif dan analisis statistik inferensial.

\section{Hasil dan Pembahasan}

Hasil dan analisis data penelitian dibuat berdasarkan data yang diperoleh dari kegiatan penelitian tentang efektivitas pembelajaran matematika melalui metode Index Card Match pada siswa kelas VII.F SMP Nasional Makassar. Adapun hasil pengamatan keterlaksanaan pembelajaran selama 4 kali pertemuan dapat dilihat pada Tabel 1 sebagai berikut:

Tabel 1. Hasil pengamatan keterlaksanaan pembelajaran selama 4 kali pertemuan

\begin{tabular}{|c|c|c|c|}
\hline Pertemuan & Rata-rata & Jumlah & Kategori \\
\hline $\mathrm{I}$ & 3,2 & 58 & Sangat Baik \\
\hline II & 3,2 & 58 & Sangat Baik \\
\hline III & 3,2 & 58 & Sangat Baik \\
\hline IV & 3,2 & 58 & Sangat Baik \\
\hline \multicolumn{2}{|c|}{ Rata-rata keseluruhan } & \multicolumn{2}{|r|}{3,2} \\
\hline
\end{tabular}

Berdasarkan Tabel 1 skor rata -rata keseluruhan keterlaksanaan pembelajaran 3,2, dapat disimpulkan bahwa keterlaksanaan pembelajaran melalui metode Index Card Match) berada dalam kategori terlaksana dengan sangat baik.

Tabel 2. Statistik Skor Hasil Belajar Matematika Siswa kelas VII.F SMP Nasional

\begin{tabular}{lccc}
\multicolumn{4}{c}{ Makassar Sebelum dan Setelah Diberikan Perlakuan (Pretest dan Posttest) } \\
\cline { 2 - 4 } Statistik & Pretest & Nilai Statistik \\
\hline Ukuran Sampel & 24 & 24 & Gain \\
Skor Ideal & 100 & 100 & 24 \\
Skor Maksimum & 78 & 98 & 100 \\
Skor Minimum & 31 & 60 & 1,00 \\
Rentang Skor & 47,00 & 38,00 & 0,43 \\
Skor Rata-rata & 58,46 & 83,25 & 0,57 \\
& & & 0,64
\end{tabular}




\begin{tabular}{lccc} 
Standar Deviasi & 12,99 & 8,49 & 0,12 \\
Median & 62,00 & 84,00 & 0,62 \\
Variansi & 168,955 & 72,196 & 0,016 \\
\hline
\end{tabular}

Berdasarkan Tabel 2 diatas dapat diketahui bahwa dari 24 sampel rata-rata pretest sebelum perlakuan adalah 58,46 dengan rentang skor 47, standar deviasi 12,99 dan variansi 168,955 . Nilai rata-rata posttest siswa adalah 83,25 dengan rentang skor 38 dan standar deviasi 8,49. Skor teritnggi pretest yang diperoleh siswa adalah 78 dan skor terendah adalah 31 sedangkan skor tertinggi untuk posttest adalah 98 dan skor terendah adalah 60 .

Tabel 3. Distribusi Frekuensi Dan Persentase Skor Hasil Belajar Matematika Siswa Kelas VII.F SMP Nasional Makassar Sebelum dan Setelah Diberikan Perlakuan.

\begin{tabular}{lllllll}
\hline \multirow{2}{*}{ No. Skor } & \multirow{2}{*}{ Kategori } & \multicolumn{2}{c}{ Frekuensi } & \multicolumn{2}{c}{ Persentase (\%) } \\
\cline { 4 - 6 } & & Pretest & Posttest & Pretest & Posttest \\
\hline 1 & $0 \leq x<65$ & Sangat Rendah & 15 & 1 & 62,5 & 4,2 \\
2 & $65 \leq x<75$ & Rendah & 6 & 1 & 25 & 4,2 \\
3 & $75 \leq x<85$ & Sedang & 3 & 11 & 2,5 & 45,8 \\
4 & $85 \leq x<95$ & Tinggi & 0 & 9 & 0 & 37,5 \\
5 & $95 \leq x \leq 100$ & Sangat Tinggi & 0 & 2 & 0 & 8,3 \\
\hline Jumlah & & 24 & 24 & 100 & 100 \\
\hline
\end{tabular}

Berdasarkan data yang diperoleh dari Tabel 3 dapat disimpulkan bahwa secara umum hasil tes siswa sebelum diterapkan metode Index Card Match terdapat 25 siswa atau 62,5\% dengan kategori sangat rendah, 6 siswa atau 25\% berada dikategori rendah maka siswa belum dikatakan tuntan secara individual, dan 3 siswa atau 12,5 berada di kategori tinggi siswa tersebut tuntas secara invidual dan secara keseluruan siswa belumtuntas secara klasikal secara. Sedangkan hasil posttest siswa terdapat 1 atau 4,2\% siswa yang berada pada kategori sangat rendah, ada 1 atau 71\% siswa berada pada kategori rendah, ada 11 atau 45,8\% siswa yang berada pada kategori sedang, ada 9 atau 37,5\% siswa berada pada kategori tinggi, dan terdapat 2 atau $8,3 \%$ siswa berada pada kategori Sangat tinggi. Berdasarkan hal tersebut hasil belajar siswa tuntas secara klasikal.

Tabel 4. Deskripsi Ketuntasan Hasil Belajar Matematika Sebelum dan Setelah Diberikan Perlakuan.

\begin{tabular}{llllll}
\hline \multirow{2}{*}{ Skor } & \multirow{2}{*}{ Kategori } & \multicolumn{2}{c}{ Frekuensi } & \multicolumn{2}{c}{ Persentase (\%) } \\
\cline { 3 - 6 } & & Pretest & Posttest & Pretest & Posttest \\
\hline $0 \leq x<75$ & Tidak Tuntas & 21 & 2 & 87,5 & 8,33 \\
$75 \leq \mathrm{x} \leq 100$ & Tuntas & 3 & 22 & 12,5 & 91,67 \\
\hline Jumlah & & 24 & 24 & 100 & 100 \\
\hline
\end{tabular}

Berdasarkan data yang diperoleh dari tabel dapat disimpulkan bahwa secara umum 
hasil tes siswa sebelum diterapkan metode Index Card Match terdapat 21 siswa dengan persentase $87,5 \%$ masih dalam kategori tidak tuntas secara individual maupun klasikal, sedangkan 3 siswa atau 12,5\% tuntas secara individual. Pada posttest terdapat 2 atau 8,33\% siswa yang berada pada kategori tidak tuntas, ada 22 atau 91,67\% siswa berada pada kategori tuntas secara individual. Berdasarkan hal tersebut hasil belajar siswa tuntas secara klasikal.

Tabel 5. Deskripsi Peningkatan Hasil Belajar Matematika Siswa Setelah Diterapkan metode Index Card Match.

\begin{tabular}{llcc}
\hline Nilai Gain & Kategori & Frekuensi & Persentase (\%) \\
\hline $\mathrm{g} \leq 0,30$ & Rendah & 0 & 0 \\
$0,30<\mathrm{g}<0,70$ & Sedang & 17 & 70,83 \\
$\mathrm{~g} \geq 0,70$ & Tinggi & 7 & 29,16 \\
\hline Jumlah & & 24 & 100 \\
\hline
\end{tabular}

Berdasarkan Tabel 5 diatas dapat dilihat bahwa ada 23 atau 70,83\% siswa yang nilai gainnya $0,30<\mathrm{g}<0,70$ yang artinya peningkatan hasil belajarnya berada ada kategori sedang kemudian ada 8 atau $25,8 \%$ siswa yang nilai $g \geq 0,70$ yang artinya peningkatan hasil belajarnya berada pada kategori tinggi dan tidak ada satupun atau $0 \%$ siswa yang peningkatan hasil belajarnya berada pada kategori rendah.

Hasil pengamatan aktivitas positif siswa melalui metode pembelajaran Index Card Match adalah $82,92 \%$ dan persentase aktivitas pasif siswa adalah 10,42\%. Sehingga aktivitas siswa melalui penerapan metode pembelajaran Index Card Match dikatakan efektif karena telah memenuhi indikator keektifan dan kriteria aktivitas siswa secara klasikal yaitu $\geq 75 \%$ siswa terlibat aktif dalam proses pembelajaran.

Data tentang respons siswa terhadap pembelajaran melalui mertode Index Card Match, rata-rata persentase respons positif siswa adalah 90,53\% dan rata-rata persentase respons negative siswa adalah $9,47 \%$, Dengan demikian respons siswa yang diajar dengan metode ini dapat dikatakan efektif karena telah memenuhi indicator keektifan yakni $\geq 75 \%$ memberikan respon positif.

Analisis inferensial pada bagian ini digunakan untuk menguji hipotesis yang telah dirumuskan Sebelum dilakukan uji hipotesis maka terlebih dahulu uji normalitas sebagai uji prasyarat. Dengan menggunakan uji Kolmogorof-smirnov, hasil analisis signifikan untuk pretest $P_{\text {value }}>\alpha$ yaitu $0,180>0,05$, hasil analisis signifikan untuk posttest $P_{\text {value }}>\alpha$ yaitu $0,200>0,05$ dan hasil analisis signifikan untuk gain $P_{\text {value }}>\alpha$ yaitu 0,200>0,05. Hal ini menunjukkan bahwa skor pretest, posttest dan gain termasuk kategori normal. Berdasarkan 
output Tabel One Sample t test diketahui nilai sig. (2 tailed) adalah 0,000 $<0,05$ dan nilai thitung 4,896 > t tabel 1,714, maka sesuai dengan dasar pengambilan keputusan dapat disimpulkan bahwa $H_{o}$ ditolak artinya hasil belajar siswa yang diajar melalui metode Index Card Match lebih dari 74,9. Pengujian ketuntasan klasikal siswa dilakukan dengan menggunakan uji proporsi (lampiran D). untuk uji proporsi dengan menggunakan taraf signifikan $5 \%$ diperoleh $Z_{\text {hitung }}=1,88978>Z_{\text {tabel }}=1,645$ maka sesuai dengan pengambilan keputusan dapat disimpulkan bahwa $H_{o}$ ditolak artinya proporsi siswa yang mencapai ketuntasan secara klasikal $(\mathrm{KKM}=75)>74,9 \%$. Berdasarkan output tabel One Sample t test diketahui nilai sig. ( 2 tailed) adalah 0,000 $<0,05$ dan nilai $t$ hitung $13,841>$ t tabel 1,714, maka sesuai dengan dasar pengambilan keputusan di atas dapat disimpulkan bahwa $H_{0}$ ditolak artinya peningkatan (gain) hasil belajar siswa yang diajar melalui metode Index Card Match > 0,30.

Hasil analisis data hasil belajar setelah diterapkan pembelajaran matematika melalui metode Index Card Match diperoleh dengan memberikan tes hasil belajar (posttest) yang menunjukkan bahwa terdapat 22 siswa atau 91,67\% dari jumlah keseluruhan 24 siswa yang mencapai ketuntasan individu (mendapat skor prestasi minimal 75). Siswa yang tidak mencapai ketuntasan individu sebanyak 2 siswa atau 8,33\%. Dengan kata lain hasil belajar siswa setelah diterapkan metode Index Card Match mengalami peningkatan karena tergolong kriteria sedang, tinggi dan sangat tinggi serta sudah memenuhi kriteria ketuntasan klasikal. Normalized Gain atau peningkatan siswa setelah diajar melalui metode Index Card Match adalah 0,64. Dari beberapa analisis data mengenai hasil belajar siswa setelah diterapkan metode Index Card Match, hal ini relevan dengan penelitian yang dilakukan oleh Ahmad, 2018, menyimpulkan bahwa menggunakan metode Index Card Match Siswa kelas VIII SMPN 1 Sanrobone kabupaten Takalar Tahun Pelajaran 2017/2018 setelah mengikuti metode pembelajaran Index Card Match berada dikategori baik. Hasil penelitian metode Index Card Match pada pembelajaran matematika siswa setelah diberi perlakuan dikelas eksperimen sebesar 69,90\%.

Hasil pengamatan aktivitas siswa pada pembelajaran matematika melalui penerapan metode Index Card Match pada siswa kelas VII SMP Nasional Makassar menunjukkan bahwa siswa saling berdiskusi dalam menyelesaikan masalah, menanggapi hasil presentase antar kelompok, mencocokan pasangan kartu indeks, serta mengikuti arahan dari guru dalam pembentukan kelompok. Berdasarkan hasil analisis data pada lembar observasi aktivitas siswa menunjukkan rata-rata persentase jumlah siswa yang aktif pada saat proses pembelajaran adalah $82,92 \%$ dari aktivitas aktif siswa dan $10,42 \%$ dari aktivitas pasif siswa. Hal ini berarti bahwa 
pembelajaran matematika dengan menggunakan metode Index Card Match dapat mengakibatkan adanya perubahan aktivitas dan pandangan siswa terhadap pembelajaran matematika yang di tunjukan oleh persentase respons positif siswa 82,92\%.

Hasil pengolahan data angket respons siswa setelah mengikuti pembelajaran dengan mengunakan metode Index Card Match bahwa secara umum siswa memberi respons positif terhadap pembelajaran dengan menggunakan metode Index Card Match. Persentase rata-rata frekuensi siswa yang memberikan respons positif atau jawaban YA terhadap pembelajaran matematika dengan penerapan metode Index Card Match yang mencapai 90,53\% telah memenuhi kriteria yang menjadi tolak ukur penilaian respons siswa yaitu respons siswa terhadap pemebelajaran dikatakan posistif jika persentase respons siswa dalam menjawab senang atau YA untuk tiap poin pertanyaan minimal 75\%.

Berdasarkan hsil pengamatan penelitian yang telah dilakukan, dapat diketahui bahwa pelaksanaan pembelajaran yang dilakukan Selma empat pertemuan sudah terlaksana dengan baik. Hal ini terlihat dari nilai rata - rata aspek pengamatan keterlaksanaan pembelajaran dengan menggunkan metode Index Card Match yang mencapai nilai 3,2 dan berada pada kategori terlaksana dengan sangat baik.

Dari hasil pembahasan analisis deksriptif dan analisis inferensial ternyata cukup mendukung teori yang telah dikemukakan pada kajian pustaka. Penelitian ini relevan dengan beberapa penelitian-penelitian yang pernah dilakukan sebelumnya. Berdasarkan hal diatas dapat disimpulkan bahwa metode Index Card Match efektif diterapkan dalam pembelajaran matematika pada siswa kelasVII SMP Nasional Makassar.

\section{Kesimpulan dan Saran}

Berdasarkan hasil analisis data dan pembahasan yang telah dikemukakan maka diambil beberapa kesimpulan bahwa: Keterlaksanaan pembelajaran matematika melalui metode Index Card Match mencapai nilai rata-rata 3,2 dan terlaksana dengan sangat baik. Hasil belajar matematika yang dicapai siswa kelas VII.F SMP Nasional Makassar memperoleh rata-rata (posttest) 83,25 dengan standar deviasi 8,49. Hasil ini juga menunjukkan bahwa dari jumlah keseluruhan 24 siswa terdapat 22 siswa atau 91,97\% yang tuntas hasil belajarnya (mencapai skor minimal 75) dan jumlah siswa yang tidak memenuhi kriteria ketuntasan individu adalah 2 atau $8,33 \%$ siswa. Kemudian rata-rata gain ternormalisasi atau normalized gain pada hasil belajar siswa adalah 0,64 . Nilai gain tersebut berada pada kategori sedang. Rata-rata persentase frekuensi aktivitas siswa kelas VII.F SMP Nasional Makassar adalah 82,92\%, dengan indikator keberhasilan aktivitas siswa sekurang-kurangnya 75\%, dengan demikian aktivitas siswa 
mencapai kriteria aktif. Respons siswa melalui metode pembelajaran Index Card Match pada pembelajaran matematika siswa kelas VII.F SMP Nasional Makassar memperoleh rata-rata persentase $90,53 \%$. Hal ini tergolong respons positif sebagaimana standar yang telah ditentukan yaitu $\geq 75 \%$. Selanjutnya telah ditunjukkan bahwa hipotesis-hipotesis penelitian (telah terbukti memenuhi indikator keefektifan sehingga dapat dikatakan bahwa metode Index Card Match efekif diterapkan dalam pembelajaran matematika pada siswa kelas VII SMP Nasional Makassar.

\section{DAFTAR PUSTAKA}

Ali, Z. N. (2017). Implementasi metode pembelajaran Index Card Match untuk meningkatkan hasil belajar pencatatan jurnal khusus siswa kelas X akutansi yahun ajaran 2016/2017. Skripsi Fakultas Ekonomi Universitas Negeri Yogyakarta. Online. Tersedia di https://eprints.uny.ac.id. (diaskes pada 1 Desember 2018)

Agus, S. (2013). Cooperative Learning Teori \& Aplikasi Paikem (Edisi Revisi). Yogyakarta: Pustaka Pelajar.

Harun, C. Z. (2013). Manajemen pendidikan karakter. Jurnal pendidikan karakter, (3).

Idham, A. (2018). Efektivitas Pembelajaran Matematika dengan menggunakan Metode Index Card Match pada Siswa Kelas VIII SMPN 1 Sanrabone Kabupaten Takalar. Skripsi tidak diterbitkan. Makassar: FKIP Unismuh Makassar.

La Fua, J., \& Zuhari, A. (2017). Penerapan Model Pembelajaran Index Card Match Dalam Meningkatkan Hasil Belajar Siswa Kelas Vb Pada Mata Pelajaran Ipa Di Sdn 1 Talaga Besar Kec. Talaga Raya Kab. Buton Tengah. Zawiyah: Jurnal Pemikiran Islam, 3(1), 3654.

Lestari, K. E., \& Yudhanegara, M. R. (2015). Penelitian pendidikan matematika. Bandung: PT Refika Aditama, 2(3).

Hamruni. (2012). Strategi Pembelajaran. Yogyakarta: Insan Madani.

Muttaqien, R. (2006). Active Learning: 101 Cara Belajar Siswa Aktif. Bandung: Nusamedia.

Mulyatiningsih, E., \& Nuryanto, A. (2014). Metode penelitian terapan bidang pendidikan. Bandung: Alfabeta.

Nurda'ali, Z. (2017). Implementasi Metode Pembelajaran Index Card Match Untuk Meningkatkan Hasil Belajar Pencatatan Jurnal Khusus Siswa Kelas X Akuntansi SMK Muhammadiyah 1 Tempel Tahun Ajaran 2016/2017.

Sari, F. Y. (2012). Efektivitas Penggunaan Metode Index Card Match (ICM) dalam Pembelajaran IPA Siswa Kelas V SD Negeri 02 Kemloko Kecamatan Godong Kabupaten Grobogan Semester II Tahun Pelajaran 2011/2012. Universitas Kristen Satya Wacana. 
Online. Tersedia di http://repository. uksw. edu/bitstream/123456789/848/1/T1_292008094_Judu l. pdf.(diakses pada 16 Januari 2019).

Setiyani, A. (2017). Efektivitas metode Index Card Match dan ceramah dalam meningkatkan pengetahuan perdonal Hygiene saat mentruasi remaja pada Siswa Kelas VII SMP Negeri 1 Makassar. Skripsi tiak diterbitkan. Makassar: FKIP Unismuh Makassar.

Suawrtiani, S. A. (2017). Metode Index Card Match untuk Meningkatkan Hasil Belajar Mapel IPS Kelas VI SD. Jurnal Pendidikan, 1(1), 5.

Sugiyono, P. Dr.(2017), Metode Penelitian Pendidikan: Pendekatan Kuantitatif, Kualitatif, R\&D. Cetakan Ke-25. Bandung: CV Alfabeta.

Supardi, S. E. (2013). Konsep Dasar dan Praktiknya. Jakarta: Rajawali Pers.

Susanto, A. (2013). Teori Belajar \& Pembelajaran di Sekolah Dasar. Jakarta: Kencana.

Tati, T.,Y. (2017). Penerapan strategi Index Card Match pada pembelajaran matematika siswa kelas VII SMP Negeri Karan Jaya tahun 2016/2017. Jurnal jurusan pendidikan matematika STKIP-PGRI Lubuklinggau. Online. Tersedia di http://mahasiswa.mipastkipllg.com. (diaskes pada 5 Januari 2019).

Tim pengembangan MKDP. (2013). Kurikulum \& Pembelajaran cetak ke-3. Jakarta: Rajawali Pers.

Tim penyusun FKIP Unismuh Makassar. (2014). Pedoman Penulisan Skripsi. Makassar: Panrita Press.

Uno, H. B., \& Mohamad, N. (2011). Belajar dengan Pendekatan PAILKEM: Pembelajaran Aktif Inovatif Lingkungan Kreatif Menarik. Jakarta: Bumi Aksara.

Zaini, H., Munthe, B., \& Aryani, S. A. (2008). Strategi pembelajaran aktif. Yogyakarta: Pustaka Insan Madani, 89, 2008. 